\title{
Bioinformatic prediction of the AP2/ERF family genes in Eucalyptus grandis: focus on the CBF family
}

\author{
Sahar Azar, Helène SanClemente, Gilles Marque, Christophe Dunand, Christiane Marque*, Chantal Teulieres \\ From IUFRO Tree Biotechnology Conference 2011: From Genomes to Integration and Delivery \\ Arraial d'Ajuda, Bahia, Brazil. 26 June - 2 July 2011
}

\section{Background}

Due to their very high economic importance, Eucalyptus tree species are among the most planted hardwoods in the world with over 20 million hectares. However, as long-lived evergreen species, this genus is particularly exposed to cold. Frost tolerance varies among species and is inversely correlated to productivity. The AP2/ERF gene family includes developmentally and physiologically important transcription factors characterized by the presence of the AP2/ERF DNA-binding domain. AP2 proteins contain two AP2-like domains and RAV family proteins contain one AP2 domain and one B3 domain. ERF family proteins exhibit only one AP2 domain and are further divided into the DREB subfamily and the ERF subfamily [1]. The CBF/DREB1 protein differ from the other DREB proteins by the presence of "signature sequences" (PKK/RPAGRxKFxETRHP and DSAWR) flanking the DNA-binding AP2 domain [2]. The DREB factors recognize the $\mathrm{C}$-repeat or dehydration response element (DRE) in the promoters of low temperature and/or water deficit responsive genes and would play a crucial role in response to abiotic stresses. CBF/DREB1 are the key regulators of the cold-responsive (COR) genes. So far CBF transcription factors have been mainly characterized in model plants such as Arabidopsis, but lately they were identified in several tree species including Eucalyptus [2]. The Eucalyptus cold tolerance was greatly improved in our hands when two genes from the four CBF members isolated from a tolerant species E. gunnii were individually constitutively overexpressed in the frost sensitive E. urophylla $\mathrm{x} E$. grandis hybrid [3]. In the present study E. grandis AP2/ERF family

\footnotetext{
* Correspondence: teulieres@|rsv.ups-tlse.fr
} UMR5546 University of Toulouse, France genes were identified based on the presence of putative encoding AP2-domain(s) and were studied with regard to the model herbaceous Arabidopsis as well as the main sequenced woody plants. Within this family, a part of the study focused on the CBF/DREB1 subfamily which was compared to the four genes already characterized in E. gunnii[2].

\section{Methods}

We used the available annotated E. grandis genome sequence at phytozome (http://www.phytozome.net/ eucalyptus.php), the Arabidopsis thaliana AP2/ERF family downloaded from the DATF (Database of Arabidopsis Transcription Factors) database website (http:// datf.cbi.pku.edu.cn/), and the sequences of AP2/ERF gene family from the grapevine, and the poplar obtained from several publications. In order to get the exhaustive gene AP2 family and the location of the genes of the $E$. grandis genome, we used Scipio [4]. Every identified protein was analyzed for structural motifs by scanning them against PROSITE patterns and profiles (http:// www.expasy.org/prosite) and against Pfam (http://pfam. sanger.ac.uk/) to make sure of the presence of AP2 and/or the B3 domains. A fine correction of the predicted AP2/ERF proteins was performed. In order to identify all the members of CBF subfamily, a search within the E. grandis annotated AP2/ERF family was performed using consensus sequence including the two highly conserved signatures (PKKPAGR and DSAWR) surrounding the DNA-binding AP2-domain. As a check, we confirmed by blasting the sequences on the NCBI blast page. From a multiple alignment analysis performed with Clustal W, the phylogenetic trees were generated using MEGA version 5. The resulting

(c) $2011 \mathrm{~d}=$ "A1" et al; licensee BioMed Central Ltd. This is an open access article distributed under the terms of the Creative Commons 
phylogenetic trees were based on the maximum likelihood (ML) method [5].

\section{Results and main conclusions}

Based on the sequence alignement, the phylogenetic analyses, and the known criteria described in litterature, this study revealed that the annotated AP2 genes from $E$. grandis were divided into the four subgroups already described for Arabidopsis (DREB, ERF subfamilies, AP2 subfamily and RAV subfamily). The two subfamilies DREB and ERF were separated according to the similarity of the sequences of the AP2/ERF domain and to the amino acid at 14 and 19 positions. Distribution of the DREB members in the four dicotyledonous plant genomes (Vitis, Arabidopsis, Populus and Eucalyptus) shows similarities between grapevine and E. grandis except for the A1 subgroup which corresponds to the $\mathrm{CBF}$ genes. Interestingly this group is much larger in E. grandis compared to the three other plant species. The 17 CBF genes (including one pseudogene) identified on $E$. grandis genome exhibit a very good conservation when compared to the E. gunnii CBF genes. The $E$. grandis CBF genes could be classified into the four groups (a, b, c et d) described for E. gunnii CBF. Most of the $E g r C B F$ were localized on the chromosome 1, one member is on the chromosome 4 and the last two on the chromosome 5 .

Published: 13 September 2011

\section{References}

1. Sakuma Y, Liu Q, Dubouzet J, Abe H, Shinozaki K, Yamaguchi-Shinozaki K: DNA-binding specificity of the ERF/AP2 domain of Arabidopsis DREBs, transcription factors involved in dehydration- and cold-inducible gene expression. Biochem Biophys Res Commun 2002, 290:998-1009.

2. Navarro M, Marque G, Ayax C, Keller G, Borges JP, Marque C, Teulieres C: Complementary regulation of four Eucalyptus $\mathrm{CBF}$ genes under various cold conditions. J Exp Bot 2009, 60:2713-2724.

3. Gamboa MC, Rasmussen-Poblete S, Valenzuela PD, Krauskopf E: Isolation and characterization of a CDNA encoding a CBF transcription factor from E. globules. Plant Physiol Biochem 2007, 45:1-5.

4. Odronitz F, Pillmann H, Keller O, Waack S, Kollmar M: Webscipio: An online tool for the determination of gene structures using protein sequences. BMC Genomics 2008, 9(1):422.

5. Felsenstein J: Confidence limits on phylogenies: An approach using the bootstrap. Evolution 1985, 39:783-791.

\section{Submit your next manuscript to BioMed Central and take full advantage of:}

- Convenient online submission

- Thorough peer review

- No space constraints or color figure charges

- Immediate publication on acceptance

- Inclusion in PubMed, CAS, Scopus and Google Scholar

- Research which is freely available for redistribution

Submit your manuscript at www.biomedcentral.com/submit
C Biomed Central 